\title{
Gas Hydrate Measurements at Hydrate Ridge Using Raman Spectroscopy
}

\author{
K.C. Hester ${ }^{1}$, R.N. Dunk ${ }^{2}$, S.N. White ${ }^{3}$, P.G. Brewer ${ }^{2}$, E.T. Peltzer ${ }^{2}$, and E.D. Sloan ${ }^{1, *}$ \\ ${ }^{1}$ Center for Hydrate Research, Colorado School of Mines, Golden, CO 80401, U.S.A. \\ ${ }^{2}$ Monterey Bay Aquarium Research Institute, 7700 Sandholdt Road, Moss Landing, CA 95039, U.S.A. \\ ${ }^{3}$ Dept. of Applied Ocean Physics \& Engineering, Woods Hole Oceanographic Institution, Woods Hole, \\ MA 02543, U.S.A.
}

* Corresponding author. Tel.: +1-303-273-3723; fax: +1-303-273-3730. E-mail address: esloan@mines.edu (E.D. Sloan) 


\begin{abstract}
Oceanic gas hydrates have been measured near the seafloor for the first time using a seagoing Raman spectrometer at Hydrate Ridge, Oregon, where extensive layers of hydrates have been found to occur near the seafloor. All of the hydrates analyzed were liberated from the upper meter of the sediment column near active gas venting sites in water depths of 770-780 m.
\end{abstract}

Hydrate properties, such as structure and composition, were measured with significantly less disturbance to the sample than would be realized with core recovery. The natural hydrates measured were sI, with methane as the predominant guest component, and minor/trace amounts of hydrogen sulfide present in three of the twelve samples measured. Methane large-to-small cage occupancy ratios of the hydrates varied from 1.01 to 1.30 , in good agreement with measurements of laboratory synthesized and recovered natural hydrates

Although the samples visually appeared to be solid, varying quantities of free methane gas were detected, indicating the presence of occluded gas a hydrate bubble fabric and/or partial hydrate dissociation in the under-saturated seawater. 


\section{INTRODUCTION}

Gas hydrates are naturally occurring compounds that form in permafrost and ocean margin regions. These materials form when water and light "guest" molecules, such as methane, react at low temperature, high pressure conditions (typically 275-285 K and 2.5 to $11 \mathrm{MPa}$ for methane hydrate). The water crystallizes into a network of hydrogenbonded molecular cages that contain the guest molecules (SLOAN, 1998). Hydrates highly concentrate gases such as methane, e.g. $1 \mathrm{~m}^{3}$ of methane hydrate can contain the equivalent of $164 \mathrm{~m}^{3}$ of methane at STP (SLOAN, 1998).

The three main gas hydrate structures are sI, sII, and sH. The sI hydrate crystal has a unit cell that consists of six large $\left(5^{12} 6^{2}\right)$ cages and two small $\left(5^{12}\right)$ cages. Gases such as methane, carbon dioxide, and hydrogen sulfide form the sI framework. The sII hydrate unit cell has eight large $\left(5^{12} 6^{4}\right)$ cages and sixteen small $\left(5^{12}\right)$ cages. Larger components such as propane form sII hydrate. The sH unit cell has three cage types: one large $\left(5^{12} 6^{8}\right)$, two medium $\left(4^{3} 5^{6} 6^{3}\right)$, and three small $\left(5^{12}\right)$ cages. The sH hydrate requires a large guest, such as i-pentane, along with a smaller guest like methane (SLOAN, 1998).

In the natural environment, methane constitutes over $99 \%$ of the guest molecules in hydrates (KVENVOLDEN, 1995). Due to this predominance of methane, sI is believed to be the most common naturally occurring hydrate structure. However, sII also occurs in some areas due to the presence of ethane, propane and other higher hydrocarbons, mainly from thermogenic sources (SLOAN, 1998). In some areas, such as the Gulf of Mexico and the 
Barkley Canyon, the formation of sH hydrate has also been inferred from the presence of sH-forming hydrocarbons (SASSEN and MACDONALD, 1994; POHLMAN et al., 2005).

Research is ongoing into the importance of gas hydrates within the global carbon cycle and hence climate change (Dickens, 2001; Milkov et al., 2003; MiLKov, 2005). The majority of natural gas hydrate accumulations are found in the marine environment, where this reservoir is estimated to be at least two orders of magnitude greater than the permafrost hydrate reservoir (KVENVOLDEN, 1999). Based on current available knowledge of gas hydrate distributions, Milkov (2004) estimated a total reservoir of 5002,500 Gt of carbon stored as methane hydrate on the continental shelves of the world's oceans. Conversely, Klauda and Sandler (2005) present a significantly larger estimate of 74,200 Gt of carbon based on a predictive thermodynamic model. Even with the uncertainty in these estimates, this inventory of methane has created much of the present research interest in hydrates as a possible potential energy source for the future.

Raman spectroscopy, a non-destructive, non-invasive technique, is used to study vibrational modes of molecules (LONG, 1977), to extract information about the system of interest. This technique is now routinely employed to investigate the properties, including structure and composition, of both synthetic and recovered naturally occurring hydrates (Sum et al., 1997; UCHIDA et al., 1999; TULK et al., 2000; KoH, 2002). For pure methane hydrate, the Raman technique can quantitatively determine the relative occupancies of the two hydrate cage types (SUBRAmAniAn, 2000; WiLson et al., 2002). For mixed hydrate guests, the technique can determine hydrate composition only qualitatively. Further 
studies will be needed to allow quantification of mixed hydrate systems. Work has been done to make Raman quantitative for other geochemical applications, such as molar compositions in the gaseous and aqueous phases and in fluid inclusion analysis (SEITZ et al., 1987; SEITZ et al., 1993; SEITZ et al., 1996; DunK et al., 2005; WHite et al., 2006).

While measuring hydrates with Raman spectroscopy is now becoming routine in the laboratory, the application of this technique to oceanic field work is still relatively new. The MBARI-designed seagoing Raman spectrometer, DORISS, has been deployed to perform laboratory quality measurements on natural ocean systems at depth (BREWER et al., 2004; PASTERIS et al., 2004; White et al., 2006). Synthetic gas hydrates were measured in an ocean environment at $1000 \mathrm{~m}$ depth to qualify the use of this remote Raman technique on gas hydrates (HESTER et al., 2006). The spectra obtained were of high quality (high signal to noise ratio) and were similar to the corresponding spectra obtained in the laboratory. The next step was to attempt to measure natural hydrates on the seafloor with the field Raman spectrometer.

An important question remains as to what extent the recovery process alters the hydrate from its in situ properties. Pressurized coring techniques have made significant progress in the recovery of hydrate samples, reducing dissociation in comparison to traditional coring (ABEGG et al., 2003; TREHU et al., 2003; MiLKOv et al., 2004). Nevertheless, it is still difficult to quantify the changes in the sample over the recovery process. Here we present results from an alternative approach to minimize sample degradation prior to analysis. In this study, we use a remotely deployed Raman spectrometer to sample 
hydrates at the seafloor (i.e. rather than bring the sample to the instrument, we took the instrument to the sample). These results are compared to spectroscopic measurements on synthetic laboratory and recovered natural hydrate samples.

\section{GEOLOGICAL SETTING}

Hydrate Ridge is located at around $44-45^{\circ} \mathrm{N}, 125-126^{\circ} \mathrm{W}$ on the Cascadia Margin (Fig. 1). It is an accretionary ridge formed as the Juan de Fuca plate subducts beneath the North American plate. The rapid growth of this ridge incorporated organic-rich material leading to a hydrologically dynamic environment, including cold seeps and gas hydrates (TYron et al., 2002). The two summits at Hydrate Ridge are at a water depth of around $600 \mathrm{~m}$ for the northern summit and $800 \mathrm{~m}$ for the southern summit. This area has been extensively studied, including two ODP legs, 146 (WESTBROOK et al., 1994) and 204 (TREHU et al., 2003).

The summits are areas of active episodic venting of fluids and gases, with gas hydrates found associated with these gas vents (SUESS et al., 2001; TYron et al., 2002; TreHU et al., 2003). The fluid flow in this area is highly heterogeneous and likely migrates through a complex fracture network driven by a high gas pressure driving force (TYRON et al., 2002; TREHU et al., 2004). Formation of gas hydrate in these fracture networks occurs in the GHSZ (gas hydrate stability zone) contributing to the free gas pathways being temporally variable (TREHU et al., 2004). 
Associated with the free gas and the gas venting sites, gas hydrate has been found below the seafloor in these areas. Milkov et al. (2003) has estimated that the seafloor hydrates may contain up to $3 \times 10^{8} \mathrm{~m}^{3}$ of methane gas at STP. The composition of previously recovered seafloor hydrates recovered from Southern Hydrate Ridge was found to be predominantly microbial methane. However in some hydrate samples, thermogenic hydrocarbons were present in sufficient quantities (e.g. $\mathrm{C}_{3} \mathrm{H}_{8}$ up to $0.5 \%$ ) to suggest that sII intergrowths were possible. Small amounts of $\mathrm{H}_{2} \mathrm{~S}$ and $\mathrm{CO}_{2}$ were also detected (MiLKOV et al., 2005).

The thickness of these seafloor hydrates at Hydrate Ridge has been found to be on the order of centimeters and the hydrate fabric has been described as highly porous to massive (SUESS et al., 2001). From rise rates of the seafloor hydrates at Hydrate Ridge, it has been hypothesized that free gas is occluded, or trapped, in what visually appears to be the pure highly porous hydrate samples (SUESS et al., 2001; SuESS et al., 2002). Recovered hydrate from a TV-guided grab from the seafloor to the ship deck showed a bubble fabric consistent with occluded gas in the hydrate (SuEss et al., 1999). Macro pores existed in a shape of squashed gas bubbles separated by a thin layers of hydrate (SUESS et al., 2002). Recent X-ray CT measurements of a near seafloor hydrate core confirmed the presence of gas bubbles in the hydrate (ABEGG et al., 2003). The hydrate sample was pressure-cored and kept under pressure during the CT measurement.

While observed in the TV-guided grabs (SuEss et al., 1999) and the pressure cored sample measured with X-ray CT (ABEGG et al., 2003), none of the conventional ODP 
Leg 204 insulated cores showed this bubble fabric (TreHU et al., 2003). While there is much evidence that free gas does exist with hydrate in the near seafloor sediment at Hydrate Ridge (MiLKOV et al., 2004; TREHU et al., 2004), debate continues as to whether this bubble fabric is the true in situ hydrate texture or an artifact of the recovery process.

The formation of a hydrate bubble fabric (occluded gas in the hydrate) will likely depend on the formation rate of the hydrate. It has been proposed that the hydrate formation is a precipitation process, where the gas supply is slow and limited (MILKOV et al., 2004; Milkov and Xu, 2005; Milkov et al., 2005). The free gas co-existence in the surrounding sediments is due to hyper-saline pore water from ion exclusion during hydrate formation (MilKov et al., 2004; LiU and Flemings, 2006). In this formation scenario, gas bubbles should exist in the sediment but, if the hydrate formation is a slow precipitation, it is less likely to be trapped in the hydrate matrix. Alternatively, a model by Haeckel et al. (2004) has shown that seafloor hydrate accumulations at southern Hydrate Ridge can form very fast (30-40 cm within 4-10 weeks) partially from hydrate encrusted gas bubbles. A one-dimensional model for gas hydrate formation by Torres et al. (2004; 2005) also indicates that extremely high hydrate formation rates occur near the seafloor at Hydrate Ridge. This lends support to the possibility of hydrate-encrusted gas bubbles combining to form hydrate with a bubble texture (SUESS et al., 2001) along with free gas existing in the surrounding sediments (MILKOV et al., 2004). 


\section{METHODS}

\subsection{Hydrate sample preparation}

All sampling and analyses were carried out during a survey of Hydrate Ridge conducted on July 21-23, 2004, aboard the MBARI R/V Western Flyer using the remotely operated vehicle (ROV) Tiburon.

Hydrates were liberated from the sediment column using a benthic hoe and auger. The ROV robotic arm manipulated these tools to break the layers of hydrate near the gas vents and perturb the upper sediment layer $(<1 \mathrm{~m})$ holding the hydrate in place. Hydrate samples were positioned for Raman analysis using one of two sampling chambers held in the manipulator arm of the ROV; a Pyrex cylinder (3.2 liter cylindrical tube, $305 \mathrm{~mm} \mathrm{x}$ $124 \mathrm{~mm}$, Fig. 2A) with an open bottom and plastic netting over the top opening, and a PVC ring also covered with plastic netting (Fig. 2B).

\subsection{Subsea Raman Spectrometer - DORISS}

DORISS (Deep Ocean Raman In Situ Spectrometer) is a seagoing Raman spectrometer designed for deployment on ROVs (BREWER et al., 2004; PASTERIS et al., 2004). The instrument is a modified laboratory scale Raman spectrometer from Kaiser Optical Systems. The spectrometer consists of a $532 \mathrm{~nm} \mathrm{Nd:YAG} \mathrm{laser,} \mathrm{a} \mathrm{holographically} \mathrm{filtered}$ probe head, a holographic duplex grating, and a 512 x 2048 front illuminated CCD camera from Andor Technology. The spectral range of DORISS is $100-4400 \mathrm{~cm}^{-1}$. The duplex grating splits the spectrum into two strips on the face of the CCD chip providing a mapping of ca. $1 \mathrm{~cm}^{-1}$ per pixel. The full width at half maximum height (FWHM) of the 
sharpest lines in the neon spectrum was around $3.5 \mathrm{~cm}^{-1}$, giving a spectral resolution of ca. $4.4 \mathrm{~cm}^{-1}$ (according to the Rayleigh criterion) for this deployment. The spectrometer and on-board computer for communications and control were packaged in pressure housings rated to $4000 \mathrm{~m}$ depth. Power and communications to the instrument were provided through the ROV tether.

The optical probe head with a stand-off sampling optic (f/3) was contained in a titanium housing with a dome glass window (Fig. 3). A sampling geometry of $180^{\circ}$ backscattering was used. A remote stage inside of the housing moved the probe head within the housing to provide a working distance of $152 \mathrm{~mm}$ in water. The sampling volume can be estimated from the depth of field and the laser spot size. The depth of field was $3 \mathrm{~mm}$ in water, as determined experimentally using a polished silicon wafer standard. The laser spot size was on the order of tens of microns giving a sampling volume on the order of $0.001 \mathrm{~mm}^{3}$.

Frequency and intensity calibrations were performed in the laboratory and on the ship prior to deployment, using neon emission and white light. The laser power was measured on deck to be around $34 \mathrm{~mW}$. During deployment, a diamond plate placed in the beam path of the laser inside the probe head served as a frequency calibration reference (ZHENG et al., 2001); the $1332 \mathrm{~cm}^{-1}$ diamond Raman line was superimposed on all collected spectra. Spectra were acquired using KOSI's HoloGRAMS software. Dark spectrum subtraction and wavelength and intensity corrections were performed by HoloGRAMS during acquisition and the processed spectra were saved in generic spectrum (.spc) 
format. Typical accumulation times for the hydrate samples varied between 5-20 seconds for individual collections cumulatively summed over 5-20 collections. Total collection times ranged from 25 to 400 seconds.

A stand-alone Precision Underwater Positioner (PUP) was employed along with the Raman probe to provide the ability to analyze solid, opaque samples in situ (WHITE et al., 2005). The DORISS Raman probe was mounted on PUP, and once at the seafloor, the PUP was offloaded from the ROV and positioned on the seafloor. This decoupled the spectrometer from the intrinsic vibrations of the ROV, and provided for precision positioning of the laser focal point on the target sample. Controlled by a ship-board scientist, the PUP was capable of moving the probe head with a precision of $0.1 \mathrm{~mm}$ in three dimensions - two linear and one rotational. The focus stage inside the probe head provided an additional dimension of movement.

\subsection{Cage Occupancy and Deconvolution Analysis Applied to Raman Spectra}

\subsubsection{Deconvolution of instrumentally broadened Raman spectra}

Peaks in Raman spectra contain contributions from the intrinsic line shape of the vibrational mode and a line shape perturbation from the optical path of the specific Raman instrument (MiCHAELIAN and FRIESEN, 1988). Thus instrument parameters, such as slit width and optical alignment, affect the Raman peak shapes obtained- for example by changing the measured peak widths. 
The DORISS instrument was subjected to harsh conditions during the expedition, particularly during deployment and recovery. In post cruise analysis, it was found that a slight mechanical misalignment of the lens that projected onto the slit had occurred, resulting in instrumental broadening of the measured peaks and hence a decrease in spectral resolution.

To correct for this misalignment, the LUC Maximum Likelihood deconvolution algorithm (RICHARDSON, 1972) (RazorTools/6, Spectrum Square Associates) was used in GRAMS/AI to reduce the instrumental broadening. This technique characterizes the instrumental contribution to peak shape using an emission line for which the intrinsic peak shape is well known. The instrument peak shape function is then applied to all spectra to reduce the instrumental broadening and enhance the overall spectral resolution. Here we used a neon emission line at around $2930 \mathrm{~cm}^{-1}$. Fig. 4 shows a representative hydrate spectrum before and after deconvolution.

To qualify the deconvolution method, it was applied to a representative laboratory sI methane hydrate spectrum of sufficient resolution to analyze for cage occupancy without deconvolution, which was calculated to be 1.05. The iterative LUC deconvolution algorithm was applied until there were no changes in the calculated cage occupancy. After 30 iterations, the cage occupancy approached an asymptote of 1.04, in good agreement with the value before deconvolution. This LUC algorithm was then applied to Raman spectra from Hydrate Ridge. 


\subsubsection{Methane Cage occupancy calculation}

The hydrate cage occupancy is defined as $\theta_{\mathrm{L}} / \theta_{\mathrm{s}}$, where $\theta$ is the fractional occupancy of a particular hydrate cage type and the subscripts $\mathrm{L}$ and $\mathrm{S}$ indicate the large and small cages

respectively (L: $5^{12} 6^{2}$ for sI or $5^{12} 6^{4}$ for sII, S: $5^{12}$ ). This occupancy ratio can be determined from the Raman spectrum of methane by $\left(A_{L} / 3\right) / A_{S}$, where $A$ is the area of the Raman peak corresponding to the given cage type. $A_{L}$ is divided by 3 to account for the sI cage distribution.

In order to determine the peak areas, a peak fitting routine of mixed Gaussian/Lorentzian peak shapes was used in GRAMS/AI ${ }^{\circledR}$. All of the peak parameters (frequency, width, height, and peak shape) were adjusted without constraints to minimize the difference between the fit and the spectra. For the hydrate spectra, the fitting routine adjusted the peak parameters for two peaks in the $\mathrm{CH}$-stretch region to obtain the best fit to the data.

\section{RESULTS AND DISCUSSION}

\subsection{Site Observations}

At Southern Hydrate Ridge (Fig.1), two sites of active gas venting were located near the south summit at water depths of $770-780 \mathrm{~m}(\mathrm{~T}=275.4 \mathrm{~K}, \mathrm{~S}=34.52)$ by detection of the bubble plume using the ROV mounted Simrad 1000 sonar (330 kHz): site 1 (44 34. 201' $\left.\mathrm{N}, 125^{\circ} 8.794^{\prime} \mathrm{W}\right)$ and site $2\left(44^{\circ} 34.233^{\prime} \mathrm{N}, 125^{\circ} 8.886^{\prime} \mathrm{W}\right)$. Hydrate deposits were found in near surface sediments in close proximity to the gas vents at both sites. Upon perturbation, varying-sized hydrate crystals (on the order of $\mathrm{mm}^{3}$ to $\mathrm{cm}^{3}$ ) could be observed floating up from the seafloor through the water column due to the positive 
buoyancy of hydrate in seawater (SUESS et al., 2001). The rising hydrate samples were then captured for Raman analysis in one of the sampling chambers. Similar to the observations of Suess et al (2001), the presence of free gas was inferred based on the highly variable rise rates of the hydrate samples.

A third site $\left(44^{\circ} 34.235^{\prime} \mathrm{N}, 125^{\circ} 8.900^{\prime} \mathrm{W}\right)$ where active gas venting and hydrate deposits had been observed on a previous survey in 2000 (PAULL et al., 2002) was also visited. However, gas was no longer venting in this area and seafloor hydrates were found to be scarce.

Along with the marked decrease in hydrate after gas venting had ceased, the amount of hydrate liberated also decreased with distance from the sites of active gas venting. Previous modeling of gas hydrate formations at southern Hydrate Ridge indicated that restrictions can exist to gas migration laterally away from vent sites. If only limited gas can migrate laterally, the decreased amount of hydrate could be expected compared to where the gas is being rapidly expelled. The observed decreasing quantity of seafloor hydrates away from the venting sites appears to be in agreement with this laterallylimited gas migration model (MiLKOv et al., 2005).

At Northern Hydrate Ridge, there was one observed site of active gas venting around visible deposits of carbonate rock. However, the amount of hydrate found when probing the seafloor was insufficient to allow Raman measurements to be made. 


\subsection{Raman Measurements of Hydrate}

Raman spectroscopic measurements were performed on 12 hydrate samples recovered from the southern summit of Hydrate Ridge. Representative images of the hydrate samples are shown in Fig. 5. The hydrates were clear to white solids, typically ranging in size from 1-10 cm diameter, and many were covered with a thin veneer of sediment (Fig. 5A). This sediment cover was readily removed by shaking the sampling chamber for a few seconds, thereby rinsing off the sediment (Fig 5B,C).

Cleaning the sample was needed because Raman measurements using a laser in the visible light range can cause fluorescence in some materials, when an absorbed photon causes an electronic transition in a material. Fluorescence is much more intense than Raman scattering. Seafloor sediment fluoresces strongly and it is clearly detectable in the Raman spectra, if measured even in small quantities resulting in interference obstructing the Raman signals.

We note that some hydrate dissociation may have occurred during this sample collection and cleaning process as bottom water is under-saturated in methane. Nevertheless, bottom water conditions $(\mathrm{P}=77 \mathrm{bar}, \mathrm{S}=34.52, \mathrm{~T}=275.4 \mathrm{~K})$ at this site fall well within the methane hydrate stability zone for pressure and temperature (at 77 bar and a salinity of 34.52, $\mathrm{T}_{\text {sI,eq }}$ for $\mathrm{CH}_{4}$ hydrate is $282.1 \mathrm{~K}$ ) and all samples were analyzed at the seafloor within minutes of collection to minimize sample changes due to hydrate dissolution. Fig. 6 shows a Raman spectrum across the full spectral range $\left(500-4000 \mathrm{~cm}^{-1}\right)$ of a gas hydrate measured at the seafloor at Hydrate Ridge. 


\subsection{Raman Measurements of Methane in the Hydrate}

Methane was the only guest molecule detected in most of the hydrates measured, with minor $\mathrm{H}_{2} \mathrm{~S}$ observed in three of the twelve samples (see Section 4.4.). The strongest Raman active mode of methane is the $v 1$ symmetric stretch, which occurs at around 2915 $\mathrm{cm}^{-1}$ in the gas phase at 77 bar (SEITZ et al., 1993) with two much weaker bands at 3017 $\mathrm{cm}^{-1}$ (v3) and $3066 \mathrm{~cm}^{-1}$ (2v2) (HANSEN et al., 2002). There is also a weak band at around $2580 \mathrm{~cm}^{-1}$ (possibly the $2 v 4$ band). In the sI and sII hydrate phases, the $v 1$ band splits into two peaks at ca. $2905 \mathrm{~cm}^{-1}$ and ca. $2915 \mathrm{~cm}^{-1}$, representing methane occupying the large and small cages, respectively (Sum et al., 1997). Because the methane frequencies are very close between sI and sII, unambiguous hydrate structure assignment cannot be performed using the $v 1$ frequencies alone. Other minor methane hydrate Raman bands include those at $3054 \mathrm{~cm}^{-1}$ (possibly the $2 v 2$ band with the $v 3$ band not observed, shifted $-12 \mathrm{~cm}^{-1}$ from the gas phase) and $2570 \mathrm{~cm}^{-1}$ (shifted $-10 \mathrm{~cm}^{-1}$ from the gas phase) for both sI and sII. For methane dissolved in the aqueous phase, the $v 1 \mathrm{CH}_{4}$ peak occurs at ca. $2910 \mathrm{~cm}^{-1}$. Due to the low solubility of $\mathrm{CH}_{4}$ in water, only the $v 1$ band was detected in previous field experiments with dissolved methane using DORISS (HESTER et al., 2006).

\subsubsection{Methane peak variation in the hydrate Raman spectra}

In general for all the samples measured, large relative intensity variations in the 2915 $\mathrm{cm}^{-1}$ peak were observed as the Raman focus was moved across the face of a hydrate sample. Fig. 7 shows the methane $v 1$ bands for three spectra collected on different hydrate samples. The $2915 \mathrm{~cm}^{-1}$ variation was unexpected for sI methane hydrate. 
Laboratory Raman studies of synthetic and recovered methane hydrate samples have shown that the area of the $5^{12} 6^{2}$ peak around $2905 \mathrm{~cm}^{-1}$ is approximately three times that of the $5^{12}$ cage around $2915 \mathrm{~cm}^{-1}$ (Sum et al., 1997; UCHIDA et al., 1999).

There are three most probable explanations for the observed variation in the $2915 \mathrm{~cm}^{-1}$ peak: (1) the presence of dissolved methane surrounding the hydrate; (2) the simultaneous measurement of multiple hydrate structures; (3) the presence of free gas, either surrounding the hydrate structure, or occluded within the hydrate structure. Each of these possible scenarios is discussed below.

As discussed above, the removal of the hydrate from the sediment column may lead to some hydrate dissociation driven by methane dissolution into the under saturated seawater. While dissolved methane could therefore be present in the surrounding seawater, its low solubility in seawater $\left(0.001 \mathrm{gm} / \mathrm{cm}^{3}\right.$ for dissolved $\mathrm{CH}_{4}$ versus 0.1 $\mathrm{gm} / \mathrm{cm}^{3}$ for $\mathrm{CH}_{4}$ in the sI hydrate) strongly suggests that any dissolved methane contribution to the spectra would be negligible. Additionally, the frequency of the dissolved $\mathrm{CH}_{4} \mathrm{v} 1$ mode (around $2910 \mathrm{~cm}^{-1}$ for the pressure/temperature conditions of these experiments), would likely contribute to both the 2905 and $2915 \mathrm{~cm}^{-1}$ peaks. We therefore consider this explanation unlikely.

The second possibility for the $2915 \mathrm{~cm}^{1}$ peak variation could be that multiple structures were present. Previous work has shown small quantities of higher hydrocarbons present (e.g. $\mathrm{C}_{2} \mathrm{H}_{6}, \mathrm{C}_{3} \mathrm{H}_{8}$ ) in recovered hydrates from Hydrate Ridge (MiLKov et al., 2005), 
where these molecules could result in sII formation. However, only methane and minor $\mathrm{H}_{2} \mathrm{~S}$ (also a sI forming gas) were detected in the Raman spectra obtained in this study. While it can not be conclusively determined that there was no coexistence of multiple structures, the absence of sII hydrate forming components from the spectra and, as will be discussed in the next paragraph, minor bands of methane leads to the third possibility (free gas) being the most likely explanation for the measurements in this study.

Fig. 8 shows a comparison of the minor vibrational bands for methane in the gas phase, in a synthetic sI hydrate, and in a hydrate sample measured on the seafloor at Hydrate Ridge. Fig. 8A shows the two peaks corresponding to the $v 3\left(3017 \mathrm{~cm}^{-1}\right)$ and $2 v 2(3066$ $\mathrm{cm}^{-1}$ ) modes of methane in the free gas phase (HANSEN et al., 2002). For methane in a synthetic sI hydrate (Fig. 8B), only one peak is present at $3054 \mathrm{~cm}^{-1}$. In the natural hydrate spectra on the seafloor (where the ratio of the 2905 to the $2915 \mathrm{~cm}^{-1}$ was less than 3, Fig. 8C) three peaks were present between $3000-3100 \mathrm{~cm}^{-1}$. The Raman shifts of the three peaks correspond to methane in both the gas phase (two peaks at 3017 and 3066 $\mathrm{cm}^{-1}$ ) and the hydrate phase (one peak at $3054 \mathrm{~cm}^{-1}$ ). While these peaks are in the same area as the broad water $\mathrm{OH}$ stretching band, with a baseline correction added, these minor methane peaks were clearly present and the frequencies were quantifiable (Fig. 8). In determining if the minor methane peaks were present, a criterion was applied that the peak intensity must be greater than $3 \sigma$ (standard deviations) of the baseline noise.

Additionally, laboratory work has shown that free gas contributions can cause large variations in the methane hydrate Raman spectra (CHOU et al., 2005). At $770 \mathrm{~m}$ depth, the 
$v 1$ frequency for methane in the gas phase is around $2915 \mathrm{~cm}^{-1}$ (SEITZ et al., 1993). Because the frequency for methane in the $5^{12}$ cage is around $2915 \mathrm{~cm}^{-1}$, the gas and $5^{12}$ $v 1$ bands can appear as a single peak. Therefore, from the spectral evidence, the most likely scenario is that free gas was measured along with the hydrate phase. The remaining question is where is the free gas located: entrapped in the hydrate matrix or surrounding the hydrate phase?

It is an important to know if the Raman technique would be able to detect gas that was occluded in an opaque hydrate sample with a bubble fabric. An initial study showed that releasing gas in the ocean in the GHSZ led to the formation of a hydrate with a bubble fabric (BREWER et al., 1997). Raman field work later confirmed that a rapidly-formed synthetic hydrate in the ocean consisted of free gas occluded in the hydrate (HESTER et al., 2006). Visually, this synthetic methane hydrate appeared as a white solid, similar to the natural hydrates, but the Raman spectrum contained a peak for both free gas and hydrate. While these hydrate formation processes were most likely different from the natural hydrate due to lack of sediment, it was shown possible to measure occluded gas with DORISS below the surface of opaque hydrate samples with a bubble fabric.

The alternative explanation for the free gas measurements could be that a gas sheath surrounds the hydrate phase, either trapped by any remaining sediment around and/or in the hydrate structure or from hydrate dissolution in the under-saturated seawater. The lack of any fluorescence interference indicates the absence of sediments in these spectra, thus gas trapped in the sediment is unlikely to be the source of the free gas signal. 
Whether the methane released from hydrate dissolution would dissolve rapidly in the seawater, or would exist as a thin gas layer or micro bubble around the hydrate remains an unanswered question.

From the above discussion, the variation in the $2915 \mathrm{~cm}^{-1}$ peak likely could have been caused by trapped gas pockets heterogeneously distributed within these hydrate samples similar to the bubble fabric reported by other researchers (SUESS et al., 2002; ABEGG et al., 2003) and/or micro bubbles of methane present on the hydrate surface.

\subsubsection{Methane Hydrate Occupancy Ratios}

Hydrate occupancy ratios are a measure of the distribution of guest filling in the hydrate cages. Because the $v 1$ methane Raman peak is present in each of the hydrate cages, the peak areas can be integrated to obtain the occupancy ratio of the hydrate (Section 3.3.2)

Due to the overlap between the Raman peak for methane in the gas phase and in the $5^{12}$ cage, cage occupancies were calculated only for the samples with minimal gas contribution. This was determined by the absence of the minor methane gas phase peaks at 3017 and $3066 \mathrm{~cm}^{-1}$, as described in Section 4.3.1. Samples with a significant amount of gas contribution were not analyzed for cage occupancy because small changes in the gaseous methane $v 1$ peak width during peak-fitting caused large variations in the calculated methane cage occupancy ratios. It was then assumed that only the sI and gas phases of methane were present, where all bands from $2900-2920 \mathrm{~cm}^{-1}$ are assigned to the $v 1$ modes of these phases. In a natural system, it is impossible to completely eliminate the 
possibility of other contributions to the Raman spectra. However, as discussed in Section 4.3.1, limiting the analysis to methane contributions from the sI hydrate and gaseous phase is reasonable.

The results of the methane cage occupancy analysis are given in Table 1. As seen in the table, the occupancy ratio for methane varies between 1.01-1.30. These numbers are in the same range as occupancies determined from laboratory studies of methane hydrates (1.01-1.27), including both synthetic and recovered natural samples (Sum et al., 1997; RipMeester and RATClifFe, 1998; UChidA et al., 1999; Huo et al., 2003; Lu et al., 2005; RIPMEESTER et al., 2005; UCHIDA et al., 2005). The cage occupancy number shows that for methane in sI hydrate the large cage consistently contains more methane than the small cages, in agreement with the above previous observations of laboratory synthesized and recovered natural hydrate samples. If full large cage occupancy was assumed, the hydration number (molar ratio of water to hydrate guest) would range from $5.8-6.1$, in agreement with a rigorous study of the methane hydrate hydration number at various conditions (CIRCONE et al., 2005).

\subsection{Presence of Other Gases in the Hydrate}

Methane gas was the major constituent in the hydrate samples as determined by the Raman spectra. In three of the samples, the presence of $\mathrm{H}_{2} \mathrm{~S}$ was detected. The $v 1$ symmetric stretching band for $\mathrm{H}_{2} \mathrm{~S}$ has been reported at $2595 \mathrm{~cm}^{-1}$ and $2605 \mathrm{~cm}^{-1}$ for $\mathrm{H}_{2} \mathrm{~S}$ in the $5^{12} 6^{2}$ cage and the $5^{12}$ cage of sI hydrate, respectively (DuBESsY et al., 1992). 
A weak peak measured at $2595 \mathrm{~cm}^{-1}$ (Fig. 9) confirmed $\mathrm{H}_{2} \mathrm{~S}$ in the sI $5^{12} 6^{2}$ cage. While weak, the peak intensity was around $8 \sigma$ of the baseline noise ( $3 \sigma$ was used as the criteria for the limit of detection). Because the Raman scattering cross-sections are unknown for gases in the hydrate phase, the concentration of $\mathrm{H}_{2} \mathrm{~S}$ in the hydrate is not quantifiable. However, qualitatively, the concentration of $\mathrm{H}_{2} \mathrm{~S}$ in the hydrate is low, as indicated by comparison between the intensity of the $\mathrm{H}_{2} \mathrm{~S}$ versus $\mathrm{CH}_{4}$ peaks (Fig. 6). The accompanying peak at $2605 \mathrm{~cm}^{-1}$ for $\mathrm{H}_{2} \mathrm{~S}$ in the sI $5^{12}$ cage was not resolvable. However, the low concentration of $\mathrm{H}_{2} \mathrm{~S}$ in the hydrate in addition to the smaller number of $5^{12}$ cages, indicate that the noise level could be too high to resolve this peak.

Both the presence and concentration levels of $\mathrm{H}_{2} \mathrm{~S}$ in the hydrate samples measured were consistent with recent reports of gas from hydrates analyzed using gas chromatography (GC) from southern Hydrate Ridge (SuEss et al., 1999; MiLKOv et al., 2005). Analysis of hydrate gas samples collected at ODP Leg 204 show $\mathrm{H}_{2} \mathrm{~S}$ present in concentrations between 0.007 and $1.198 \mathrm{~mol} \%$. From the OPD Leg 204 samples, all the samples with $\mathrm{H}_{2} \mathrm{~S}$ were less than 1.64 mbsf (meters below seafloor). In this study, $\mathrm{H}_{2} \mathrm{~S}$ was detected in 3 of the 12 samples, all less than 1 mbsf. Suess et al. (1999) found $\mathrm{H}_{2} \mathrm{~S}$ present in hydrates less than 6 mbsf in concentrations between 1.49 and $3.07 \mathrm{~mol} \%$.

While $\mathrm{H}_{2} \mathrm{~S}$ was measured, unlike the previous GC measurements, no $\mathrm{CO}_{2}$ or hydrocarbon components other than methane were detected. While the higher hydrocarbon and $\mathrm{CO}_{2}$ molecules were not detected, we cannot conclude they were not present in small concentrations. Because this was of the first field deployment of the DORISS system to 
measure a natural hydrate system, we were unable to estimate the lowest detectable concentrations of various gas components from this work. Recent work using DORISS in situ at 500m water depth has shown the limit of detection for $\mathrm{CO}_{2}$ in the aqueous phase was $10 \mathrm{mmol} / \mathrm{kg}$ (DuNK et al., 2005).

\subsection{Water Contribution to the Raman spectra}

The focus of most Raman studies on hydrates has been on the guest molecules. In addition to the Raman signal for the hydrate guest molecules, the Raman signal for the host water cages is also present. This water band can also be used to differentiate between the liquid water and hydrate phase. The water stretching modes combine to appear as a broad spectral feature. Although it appears to be one peak, this spectral region will be referred to as the water O-H stretching Raman bands.

The experiments in this work differ from most laboratory studies of gas hydrates. Because the target is bathed in seawater and seawater is in the optical path, there will be a contribution from seawater when measuring the hydrate phase in the ocean. Since the hydrate is a solid phase of water, it is important to address the differences between the water Raman signal from both the hydrate and liquid seawater.

The Raman bands for the O-H stretching of water is a broad spectral feature from 2800$3800 \mathrm{~cm}^{-1}$. The complexity of these bands is due to the nature of the water itself. The strong hydrogen bonding in water systems causes wide distributions of both bond angles 
and lengths (WALRAFEN et al., 1997). These distributions cause broadening of the stretching bands for water.

Comparison of the Raman bands for the $\mathrm{OH}$ stretching of water for a sI methane hydrate and seawater clearly illustrates the differences between these two phases (Fig. 10). An increase in the shoulder of the water band around $3160 \mathrm{~cm}^{-1}$ occurs when liquid water is converted to solid water in the hydrate. This increase in the water band can be attributed to increased proton correlation of the water molecules (WALRAFEN et al., 1997). This proton correlation is caused by the enhanced ordering of the water molecules upon enclathration. There is also a decrease in the high frequency side of the $\mathrm{OH}$ stretching bands for water (3400-3700 $\mathrm{cm}^{-1}$ ). This decrease occurs because less water molecules remain non hydrogen bonded in the hydrate compared to the liquid phase (WALRAFEN et al., 1997).

When multiple water phases are present, the spectra obtained contain contributions from both solid and liquid phases. Therefore, the relative phase amounts can be qualitatively determined by the peak shape of the water bands and the Raman areas for the guest molecules compared to that of water.

Sulfate is known to exist in seawater and was detected from our seafloor Raman measurements. The $v 1$ (SO stretch) Raman band of the sulfate ion is around $981 \mathrm{~cm}^{-1}$ (NAKАмOTO, 1970). Because this ion is excluded during hydrate formation, monitoring this band can give a qualitative estimate of the amount of seawater versus hydrate 
measured. Using the PUP, a hydrate sample was analyzed by stepping the focus of the Raman probe from the seawater to the hydrate surface. Fig. 11 shows that as the focus moves from the seawater phase to the hydrate phase, the Raman signals for both the sulfate band and the band for methane in the hydrate changes dramatically. In Fig. 11A, as the laser focus approaches the hydrate, the sulfate peak dramatically decreases in intensity. Simultaneously, in Fig. 11b, the bands for methane in the hydrate show an increase in intensity. As expected, as the focus moves into the outer surface of the hydrate, the measured amount of seawater decreases (Fig. 11B) along with an increase in the amount of hydrate phase measured (Fig. 11B).

\section{Conclusions}

Near seafloor measurements have been performed on natural hydrates at the summit of southern Hydrate Ridge. The hydrate samples measured were all found in the upper sediment column $(<1 \mathrm{~m})$ and in areas of active gas venting. Methane was the main hydrate gas present in all samples. The only other hydrate guest detected was $\mathrm{H}_{2} \mathrm{~S}$, which was present in very small quantities in three of the twelve samples.

Methane in the gas phase, along with hydrated methane, was identified directly from the Raman spectra collected. The varying intensities of the methane Raman $v 1$ bands as well as minor methane Raman bands were employed to characterize the free gas contribution. A heterogeneous distribution of this free gas was determined by movement of the focus of the Raman on various parts of a hydrate sample. This free gas could have been from a hydrate bubble fabric or partial dissociation in the under saturated seawater. 
Methane cage occupancies in the hydrate were determined for those samples with minimal free gas interference. The cage occupancies (large to small cage occupancy ratios) ranged from 1.01-1.30, consistent with the occupancy ratios that have been obtained in other laboratory studies of both synthetic and recovered natural hydrate samples.

These are the first measurements of this type on natural hydrate samples measured near the seafloor. The results of this study show that Raman spectroscopy can be used to investigate seafloor gas hydrates. This work is a contribution to the development and qualifying of this remote Raman tool for geochemical application in the ocean.

Acknowledgments. This work was supported through National Undersea Research Program grant UAF03-0098. DORISS and PUP development was funded by a grant to MBARI from the David and Lucile Packard Foundation. The authors express their admiration and appreciation to the Captain and crew of the R/V Western Flyer and pilots of the ROV Tiburon. We also thank Patrick Hendra, John Freeman, and Jill Pasteris for helpful discussions about Raman instrumentation. Carolyn Koh is thanked for help with the spectral analysis. Technical assistance was provided by Alana Sherman, Mark Brown, Peter Walz, John Ferreira, and Randy Prickett. We thank Robert Burruss, Associate Editor, and Alexei Milkov and two anonymous reviewers for their valuable critique of this work. 


\section{References}

Abegg F., Freitag J., Bohrmann G., Brueckmann W., Eisenhauer A., Amann H., and Hohnberg H.-J. (2003) Free Gas Bubbles in the Hydrate Stability Zone: Evidence from CT Investigations under In Situ Conditions. Geophys. Res. Abstracts 5, 10342.

Brewer P., Malby G., Pasteris J., White S., Peltzer E., Wopenka B., Freeman J., and Brown M. (2004) Development of a laser Raman spectrometer for deep-ocean science. Deep-Sea Res. 51, 739-753.

Brewer P. G., Orr F. M., Friederich G., Kvenvolden K. A., Orange D. L., McFarlane J., and Kirkwood W. (1997) Deep-ocean field test of methane hydrate formation from a remotely operated vehicle. Geology 25(5), 407-410.

Chou I. M., Burruss R. C., and Lu W. (2005) Simultaneous Synthesis of Structure I and Structure II Methane Hydrates: A New Interpretation. Fifth International Conference on Gas Hydrates, 5037.

Circone S., Kirby S. H., and Stern L. A. (2005) Direct measurement of methane hydrate composition along the hydrate equilibrium boundary. J. Phys. Chem. B 109(19), 9468-9475.

Dickens G. (2001) On the fate of past gas: What happens to methane released from a bacterially mediated gas hydrate capacitor? Geochem. Geophys. Geosyst. 2, art. no.-2000GC000131. 
Dubessy J., Boiron M. C., Moissette A., Monnon C., and Sretenskaya N. (1992)

Determination of water, hydrates, and $\mathrm{pH}$ in fluid inclusions by micro-Raman spectroscopy. Eur. J. Mineral. 4, 885.

Dunk R. M., Peltzer E. T., Walz P. M., and Brewer P. G. (2005) Seeing a deep ocean CO2 enrichment experiment in a new light: Laser Raman detection of dissolved CO2 in seawater Environ. Sci. Technol. 39(24), 9630-9636.

Haeckel M., Suess E., Wallmann K., and Rickert D. (2004) Rising methane gas bubbles form massive hydrate layers at the seafloor. Geochim. Cosmochim. Acta 68(21), 4335-4345.

Hansen S. B., Berg R. W., and Stenby E. H. (2002) How to determine the pressure of a methane-containing gas mixture by means of two weak Raman bands, v3 and 2v2. J. Raman Spectrosc. 33, 160-164.

Hester K. C., White S. N., Peltzer E. T., Brewer P. G., and Sloan E. D. (2006) Raman Spectroscopic Measurements of Synthetic Gas Hydrates in the Ocean. Mar. Chem. 98, 304-314.

Huo Z., Hester K. C., Sloan E. D., and Miller K. T. (2003) Methane Hydrate Nonstoichiometry and Phase Diagram. AIChE J. 49(5), 1300-1305.

Klauda J. B. and Sandler S. I. (2005) Global Distribution of Methane Hydrate in Ocean Sediment. Energy Fuels 19, 459-470.

Koh C. A. (2002) Towards a fundamental understanding of natural gas hydrates. Chem. Soc. Rev. 31(3), 157-167.

Kvenvolden K. A. (1995) A review of the geochemistry of methane in natural gas hydrate. Org. Geochem. 23(11/12), 997-1008. 
Kvenvolden K. A. (1999) Potential effects of gas hydrate on human welfare. Proc. Nat. Acad. Sci. 96(7), 3420-3426.

Liu X. and Flemings P. B. (2006) Passing gas through the hydrate stability zone at southern Hydrate Ridge, offshore Oregon. Earth Planet. Sci. Lett. 241, 211-226.

Long D. A. (1977) Raman Spectroscopy McGraw-Hill.

Lu H., Moudrakovski I., Riedel M., Spence G., Dutrisac R., Ripmeester J., Wright F., and Dallimore S. (2005) Occurrence and structural characterization of gas hydrates associated with a cold vent field, offshore Vancouver Island. J. Geophys. Res. 110, B10204.

Michaelian K. H. and Friesen W. I. (1988) Deconvolution of Instrumental Broadening in Dispersive Raman Spectroscopy. Appl. Spectrosc. 42(8), 1538-1543.

Milkov A. V. (2004) Global estimates of hydrate-bound gas in marine sediments: how much is really out there? Earth-Sci. Rev. 66, 193-197.

Milkov A. V. (2005) Molecular and stable isotope composition of natural gas hydrates: A revised global dataset and basic interpretations in the context of geological settings. Org. Geochem. 36(5), 681-702.

Milkov A. V. and Xu W. (2005) Comment on "Gas hydrate growth, methane transport, and chloride enrichment at the southern summit of Hydrate Ridge, Cascadia margin off Oregon" by Torres et al. [Earth Planet. Sci. Lett. 226 (2004) 225-241]. Earth Planet. Sci. Lett. 239, 162-167.

Milkov A. V., Claypool G. E., Lee Y.-J., Dickens G. R., Xu W., Borowski W. S., and the ODP Leg 204 Scientific Party. (2003) In situ methane concentrations at Hydrate 
Ridge offshore Oregon: new constraints on the global gas hydrate inventory from an active margin. Geology 31, 833-836.

Milkov A. V., Dickens G. R., Claypool G. E., Lee Y.-J., Borowski W. S., Torres M. E., Xu W., Tomaru K., Trehu A. M., and Schultheiss P. (2004) Co-existence of gas hydrate, free gas, and brine within the regional gas hydrate stability zone at the southern summit of Hydrate Ridge (Oregon margin): Evidence from prolonged degassing of a pressurized core. Earth Planet. Sci. Lett. 222(3-4), 829-843.

Milkov A. V., Claypool G. E., Lee Y., and Sassen R. (2005) Gas hydrate systems at Hydrate Ridge offshore Oregon inferred from molecular and isotopic properties of hydrate-bound and void gases. Geochim. Cosmochim. Acta 69(4), 1007-1026.

Nakamoto K. (1970) Infrared spectra of inorganic and coordination compounds WileyInterscience.

Pasteris J. D., Wopenka B., Freeman J. J., Brewer P. G., White S. N., Peltzer E. T., and Malby G. (2004) Spectroscopic Success and Challenges: Raman Spectroscopy at 3.6km Depth in the Ocean. Appl. Spectrosc. 58(7), 195A-208A.

Paull C. K., Brewer P. G., Ussler W., Peltzer E. T., Rehder G., and Clague D. (2002) Evaluation of Marine Slumping as a Mechanism to Transfer Methane from Seafloor Gas Hydrate Deposits into the Upper Ocean and Atmosphere. Fourth International Conference on Gas Hydrates, 31-35.

Pohlman J. W., Canuel E. A., Chapman N. R., Spence G. D., Whiticar M. J., and Coffin R. D. (2005) The origin of thermogenic gas hydrates on the northern Cascadia Margin as inferred from isotopic (13C/12C and D/H) and molecular composition of hydrate and vent gas. Org. Geochem. 36, 703-716. 
Richardson W. H. (1972) Bayesian Iterative Method of Image Restoration. J. Optical Soc. Amer. 62, 55-59.

Ripmeester J. A. and Ratcliffe C. I. (1998) The diverse nature of dodecahedral cages in clathrate hydrates as revealed by 129Xe and 13C NMR spectroscopy: CO2 as a small-cage guest. Energy Fuels 12(2), 197-200.

Ripmeester J. A., Lu H., Moudrakovski I. L., Dutrisac R., Wilson L. D., Wright F., and Dallimore S. R. (2005) Structure and composition of gas hydrate in sediment recovered from the JAPEX/JNOC/GSC et al. Mallik 5L-38 gas hydrate production research well, determined by X-ray diffraction and Raman and solidstate nuclear magnetic resonance spectroscopy. GSC Bull. 585, 6.

Sassen R. and MacDonald I. R. (1994) Evidence of Structure H Hydrate, Gulf of Mexico Continental Slope. Org. Geochem. 22(6), 1029-1032.

Seitz J., Pasteris J., and Chou I. (1993) Raman spectroscopic characterization of gas mixtures. I. Quantitative composition and pressure determines of $\mathrm{CH} 4$, N2, and their mixtures. Am. J. Sci. 293, 297-321.

Seitz J. C., Pasteris J. D., and Wopenka B. (1987) Characterization of CO2-CH4-H2O fluid inclusions by microthermometry and laser Raman microprobe spectroscopy: Inferences for clathrate and fluid equilibria Geochim. Cosmochim. Acta 51(6), 1651-1664.

Seitz J. C., Pasteris J., and Chou I. M. (1996) Raman Spectroscopic Characterization of Gas Mixtures. II. Quantitative Composition and Pressure Determination of the CO2-CH4 System. Am. J. Sci. 296, 577-600.

Sloan E. D., Jr. (1998) Clathrate Hydrates of Natural Gases, 2nd Edition Marcel Dekker. 
Subramanian S. (2000) Measurements of Clathrate Hydrates Containing Methane and Ethane Using Raman Spectroscopy. Ph. D. thesis, Colorado School of Mines.

Suess E., Torres M. E., Bohrmann G., Collier R. W., and Greinert J. (1999) Gas hydrate destabilization: enhanced dewatering, benthic material turnover and large methane plumes at the cascadia convergent margin. Earth Planet. Sci. Lett. 170, $1-15$.

Suess E., Bohrmann G., Rickert D., Kuhs W. F., Torres M. E., Trehu A., and Linke P. (2002) Properties and Fabric of Near-Surface Methane Hydrates at Hydrate Ridge, Cascadia Margin. Fourth International Conference on Gas Hydrates, 740744.

Suess E., Torres M. E., Bohrmann G., Collier R. W., et al. (2001) Sea Floor Methane Hydrates at Hydrate Ridge, Cascadia Margin. In Natural Gas Hydrates: Occurrence, Distribution, and Detection, 124 (ed. C. K. Paull and W. P. Dillion), pp. 87-98. American Geophysical Union.

Sum A. K., Burruss R. C., and Sloan E. D. (1997) Measurement of Clathrate Hydrates via Raman Spectroscopy. J. Phys. Chem. B 101(38), 7371-7377.

Torres M. E., Wallmann K., Trehu A. M., Bohrmann G., Borowski W. S., and Tomaru H. (2004) Gas hydrate growth, methane transport, and chloride enrichment at the southern summit of Hydrate Ridge, Cascadia margin off Oregon. Earth Planet. Sci. Lett. 226, 225-241.

Torres M. E., Wallmann K., Trehu A. M., Bohrmann G., Borowski W. S., and Tomaru H. (2005) Reply to comment on: "Gas hydrate growth, methane transport, and 
chloride enrichment at the southern summit of Hydrate Ridge, Cascadia margin off Oregon". Earth Planet. Sci. Lett. 239, 168-175.

Trehu A. M., Flemings P. B., Bangs N. L., Chevallier J., Gracia E., Johnson J. E., Liu C.S., Liu X., Riedel M., and Torres M. E. (2004) Feeding methane vents and gas hydrate deposits at south Hydrate Ridge. Geophys. Res. Lett. 31, L23310.

Trehu A. M., Bohrmann G., Rack R. F., Torres M. E., et al. (2003) Proc. Ocean Drill. Program, Initial Rep. 204 Available from: Ocean Drilling Program, Texas A\&M University, College Station TX 77845-9547, USA., [CD-ROM].

Tulk C., Ripmeester J., and Klug D. (2000) The application of Raman spectroscopy to the study of gas hydrates. Ann. N.Y. Acad. Sci. 912, 859.

Tyron M. D., Brown K. M., and Torres M. E. (2002) Fluid and chemical flux in and out of sediments hosting methane hydrate deposits on Hydrate Ridge, OR, II: Hydrological processes. Earth Planet. Sci. Lett. 201, 541-557.

Uchida T., Hirano T., Ebinuma T., Narita H., Gohara K., and Mae S. (1999) Raman spectroscopic determination of hydration number of methane hydrates. AIChE J. 45(12), 2641-2645.

Uchida T., Uchida T., Kato A., Sasaki H., Kono F., and Takeya S. (2005) Physical properties of natural gas hydrate and associated gas-hydrate-bearing sediments in the JAPEX/JNOC/GSC et al. Mallik 5L-38 gas hydrate production research well. GSC Bull. 585, 10.

Walrafen G. E., Yang W. H., and Chu Y. C. (1997) Raman Evidence for the ClathrateLike Structure of Highly Super Cooled Water. In Supercooled Liquids (ACS Symposium Series 676), 21, pp. 287-308. 
Westbrook G. K., Carson B., Musgrave R. J., and Suess E. (1994) Proceedings of the Ocean Drilling Program, Initial Reports 146, p. 477, Ocean Drilling Program.

White S. N., Dunk R. M., Peltzer E. T., Freeman J. J., and Brewer P. G. (2006) In situ Raman analyses of deep-sea hydrothermal and cold seep systems (Gorda Ridge and Hydrate Ridge). Geochem. Geophys. Geosyst. 7, Q05023.

White S. N., Kirkwood W. J., Sherman A. D., Brown M. O., Henthorn R., Salamy K. A., Walz P. M., Peltzer E. T., and Brewer P. G. (2005) Development and deployment of a precision underwater positioning system for in situ laser Raman spectroscopy in the deep ocean. Deep Sea Res. I. 52(12), 2376-2386.

Wilson L. D., Tulk C. A., and Ripmeester J. A. (2002) Instrumental Techniques for the Investigation of Methane Hydrates: Cross-Calibrating NMR and Raman Spectroscopic Data. Fourth International Conference on Gas Hydrates, 614-618.

Zheng X., Fu W., Albin S., Wise K. L., Javey A., and Cooper J. B. (2001) Selfreferencing Raman probes for quantitative analysis. Appl. Spectrosc. 55(4), 382388. 


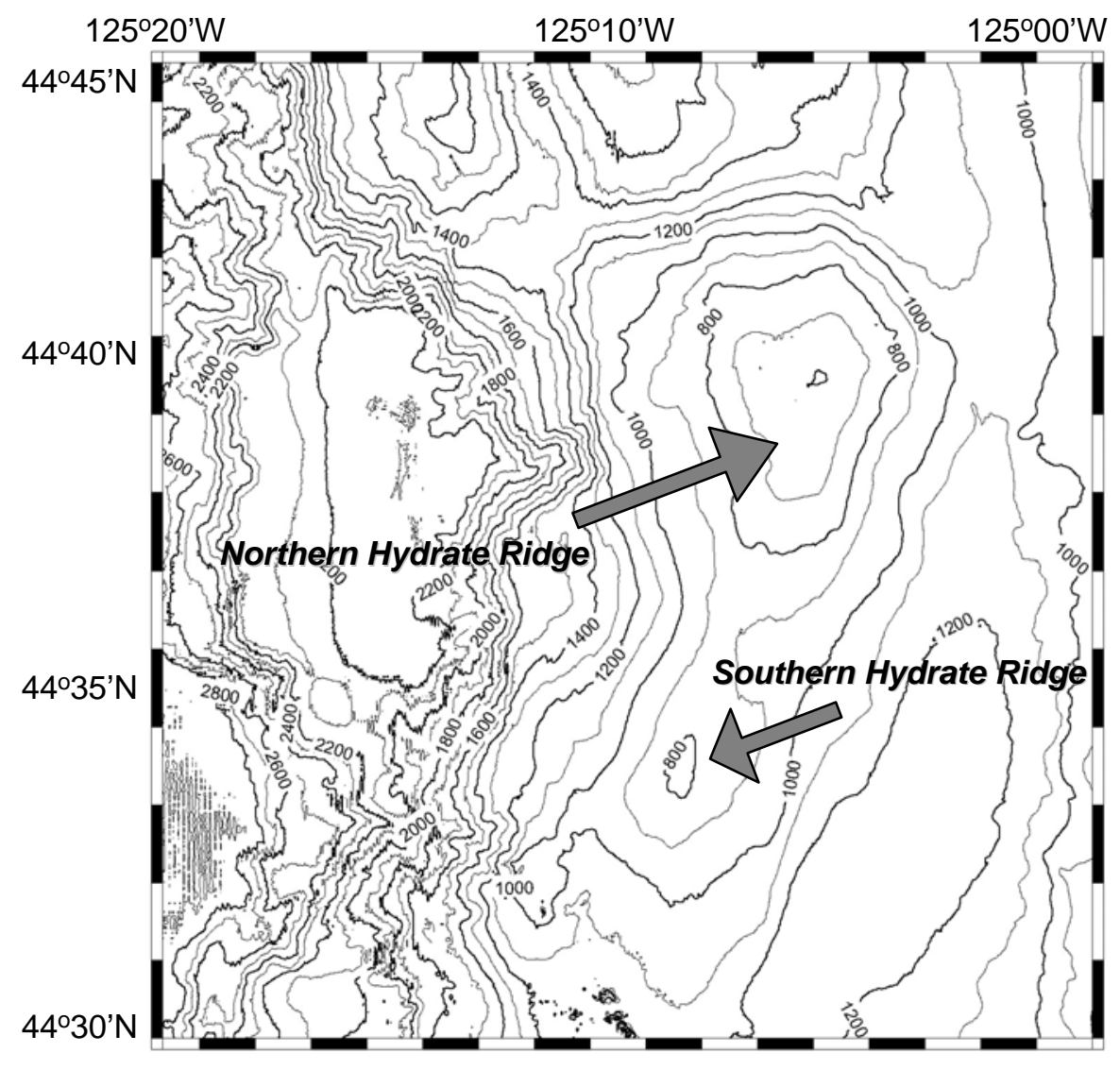

Fig. 1. Hydrate Ridge, Cascadia Margin, off the coast of Oregon, US 

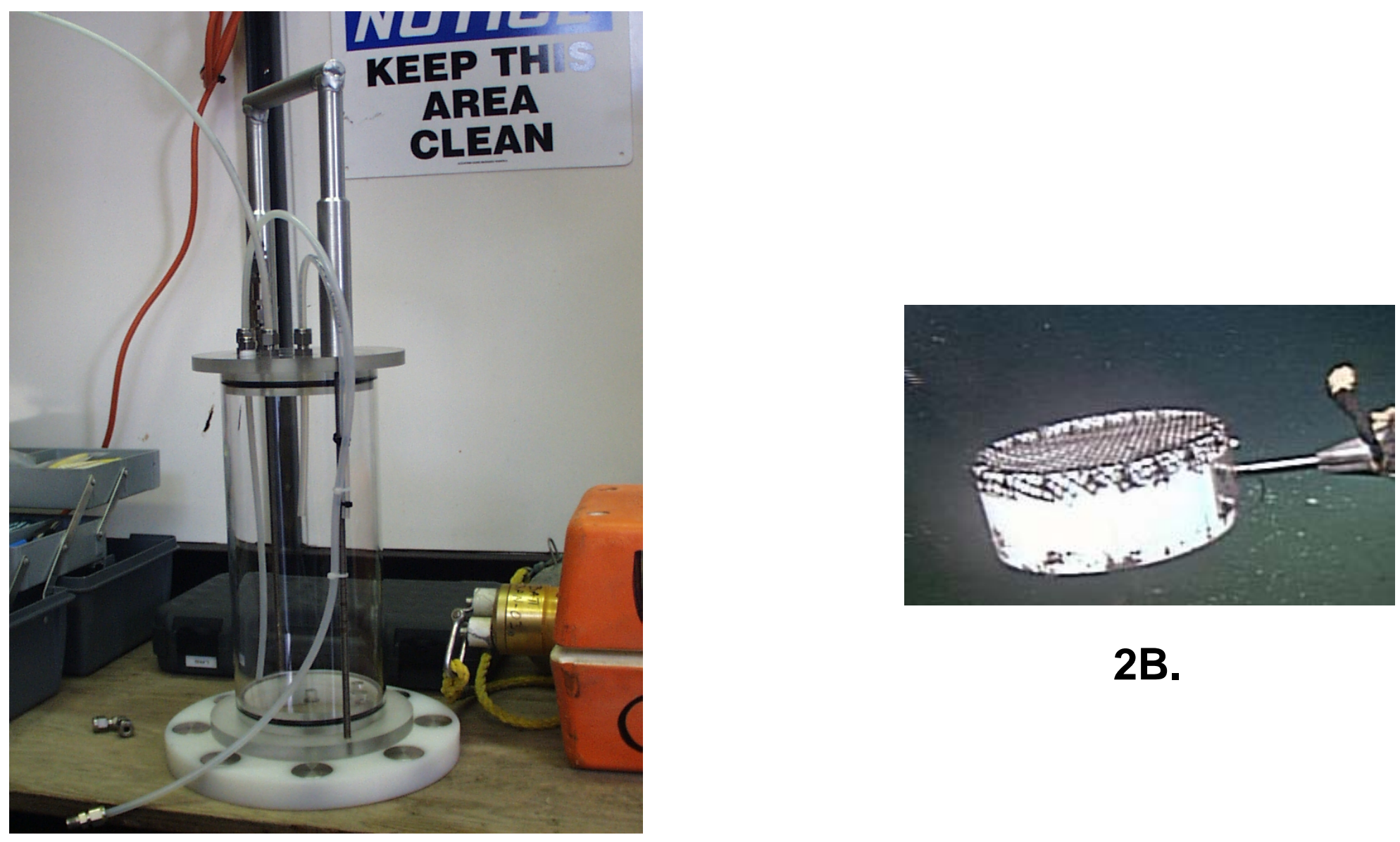

2B.

$2 A$.

Fig. 2. Pyrex cell (2A) and PVC ring (2B) cell used to hold hydrate samples for Raman measurement 


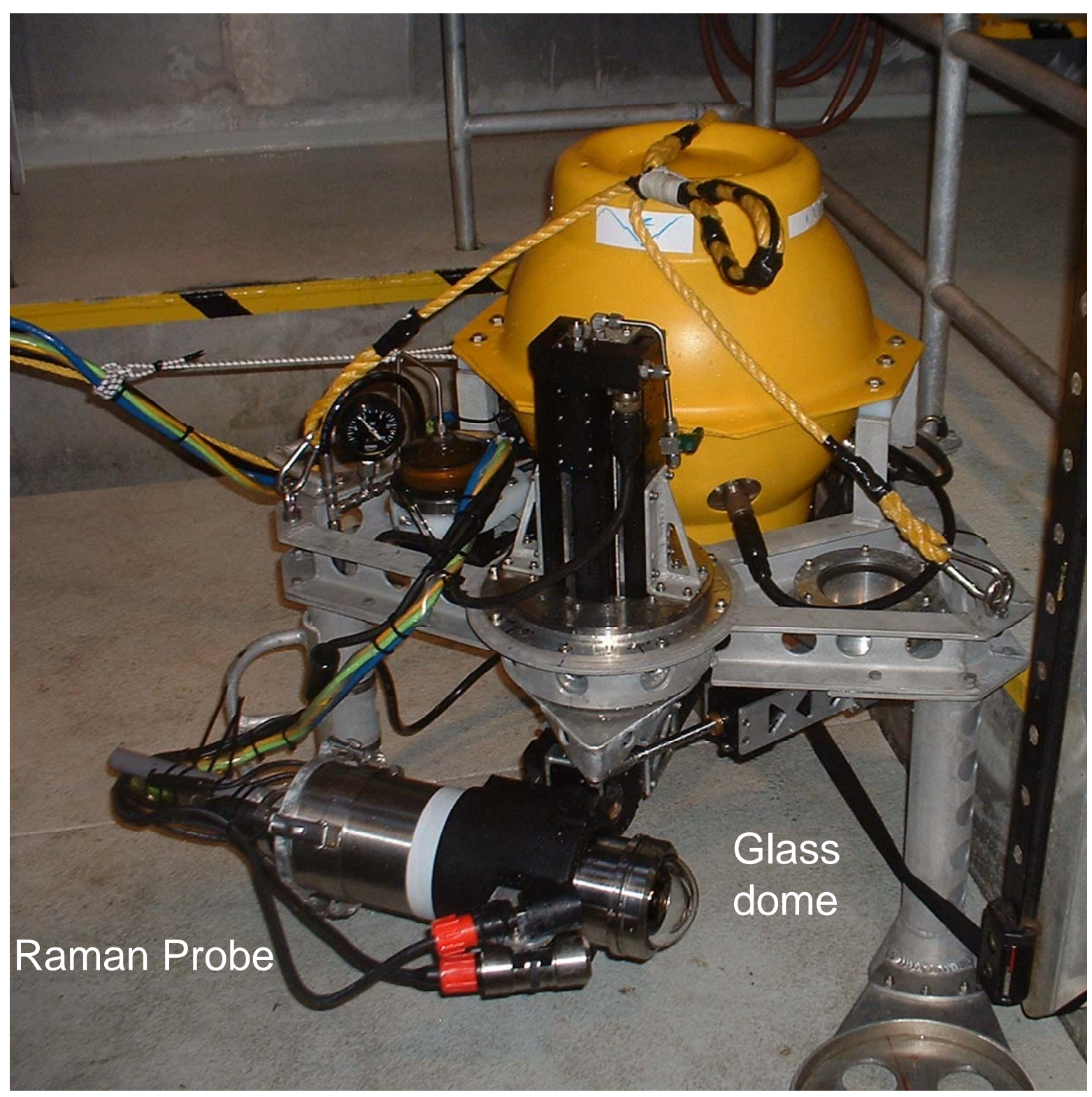

Fig. 3. Raman probe inside titanium pressure housing attached to the PUP. 




Fig. 4. Raman spectra of methane hydrate measured near the seafloor at Hydrate Ridge: Original (dashed line), After deconvolution (solid line). (150 sec, $15 \mathrm{sec}$ X 10) 


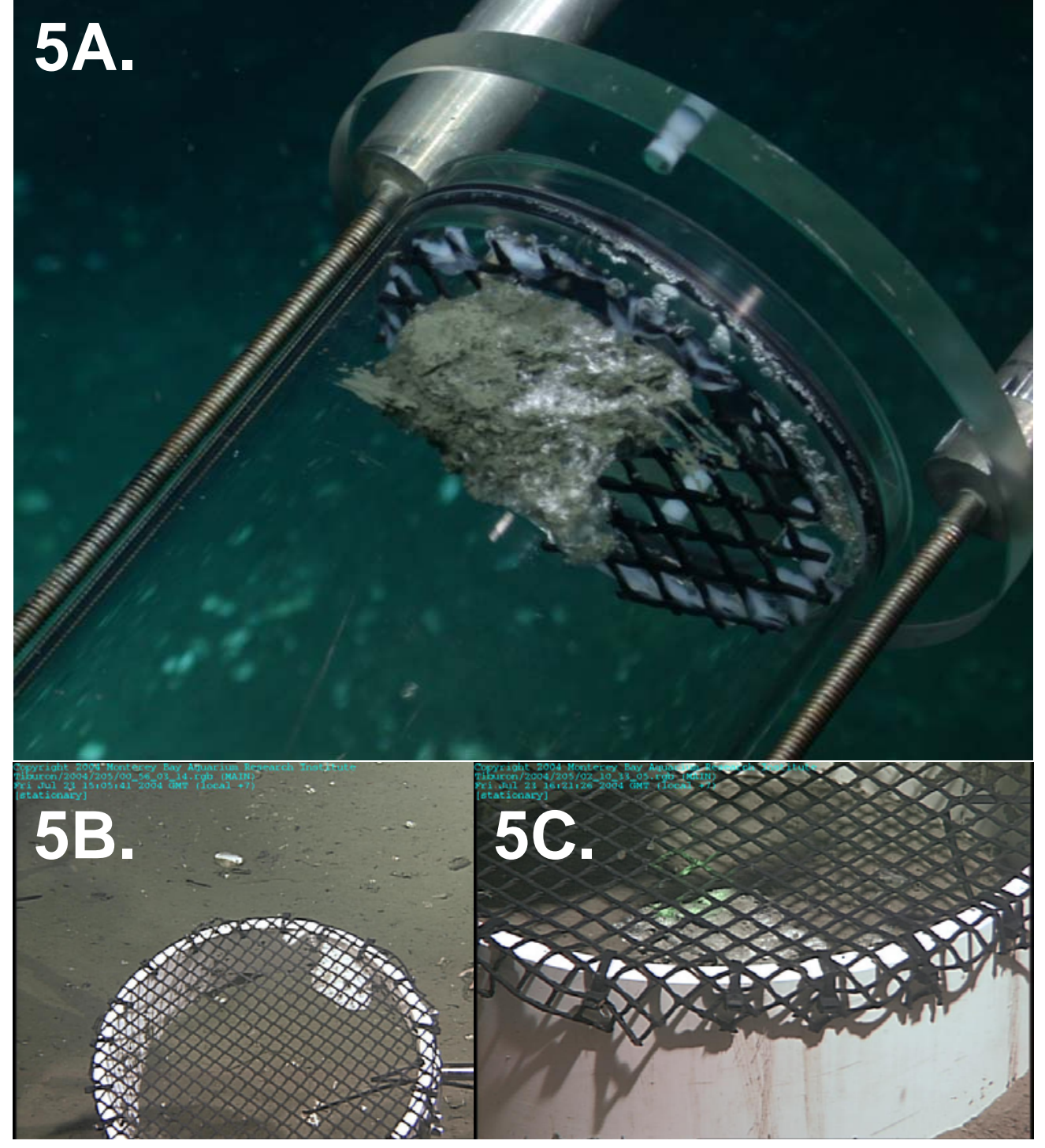

Fig. 5. Hydrate samples in Raman sampling cells at Hydrate Ridge 


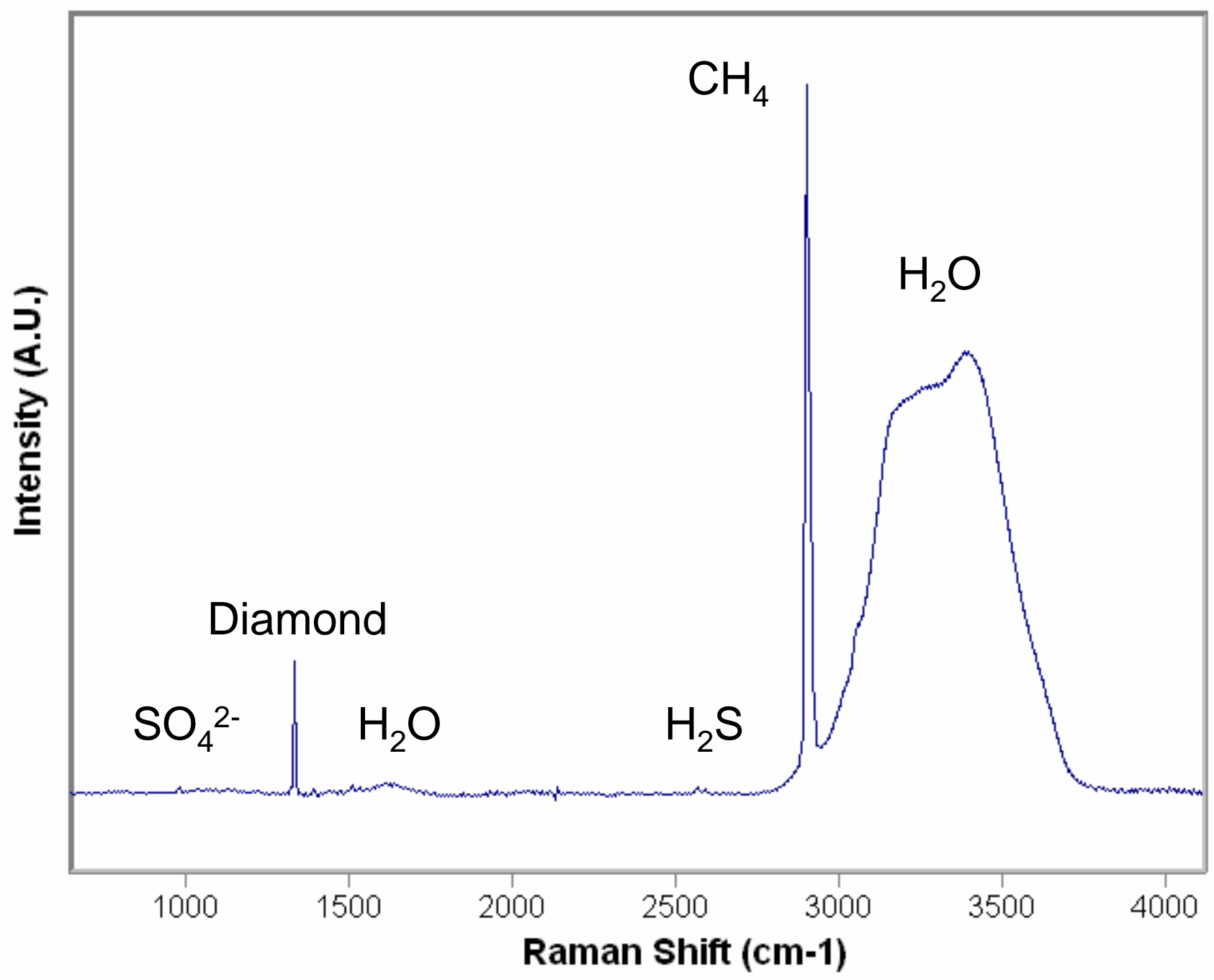

Fig. 6. A typical hydrate spectrum measured near the seafloor at Hydrate Ridge. (400 sec, $20 \mathrm{sec} X 20$ ) 


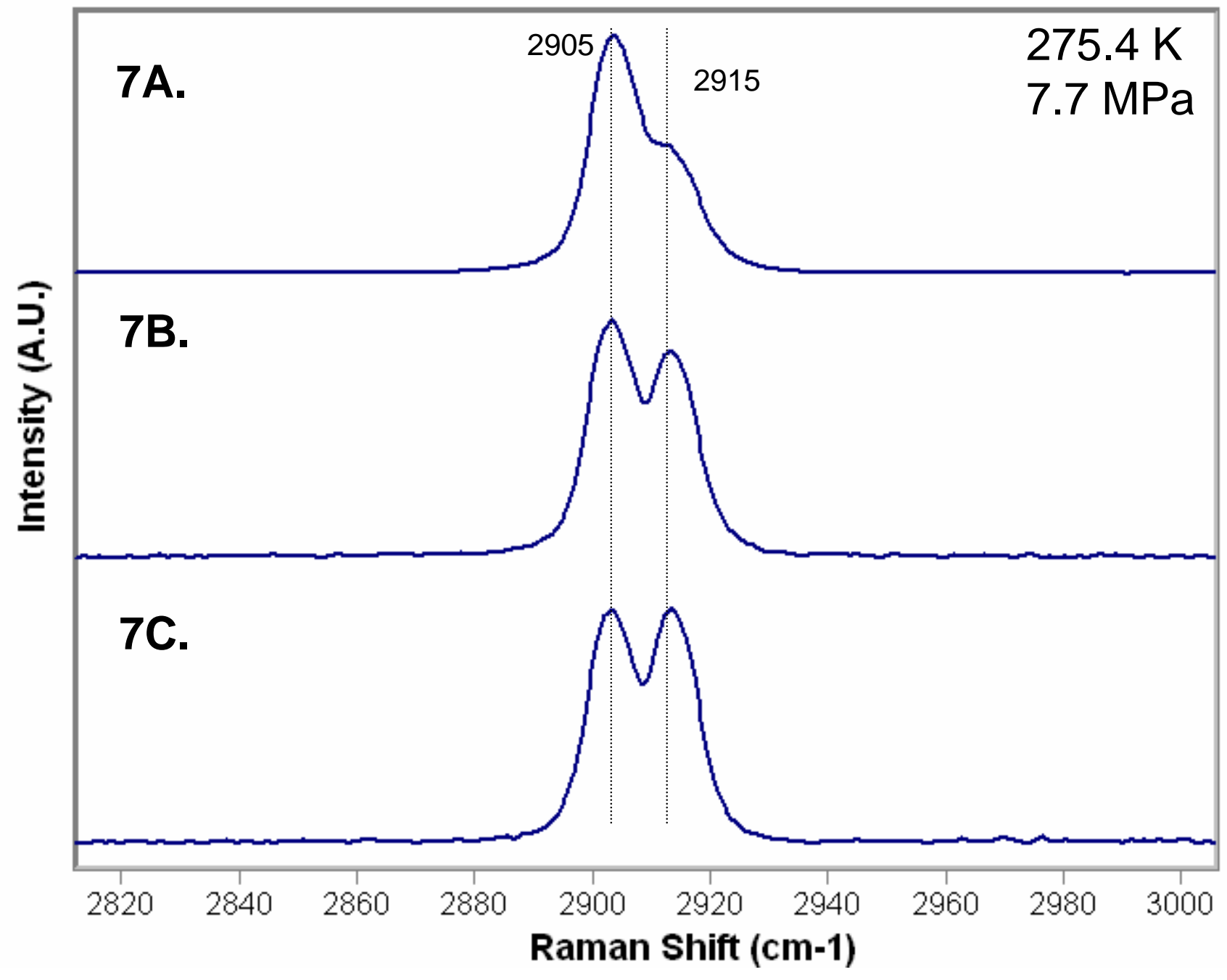

Fig. 7. Representative in situ Raman spectra of natural hydrate samples. Note the variability in the peak intensity around $2915 \mathrm{~cm}^{-1} .(200 \mathrm{sec}, 20 \mathrm{sec} \times 10)$ 


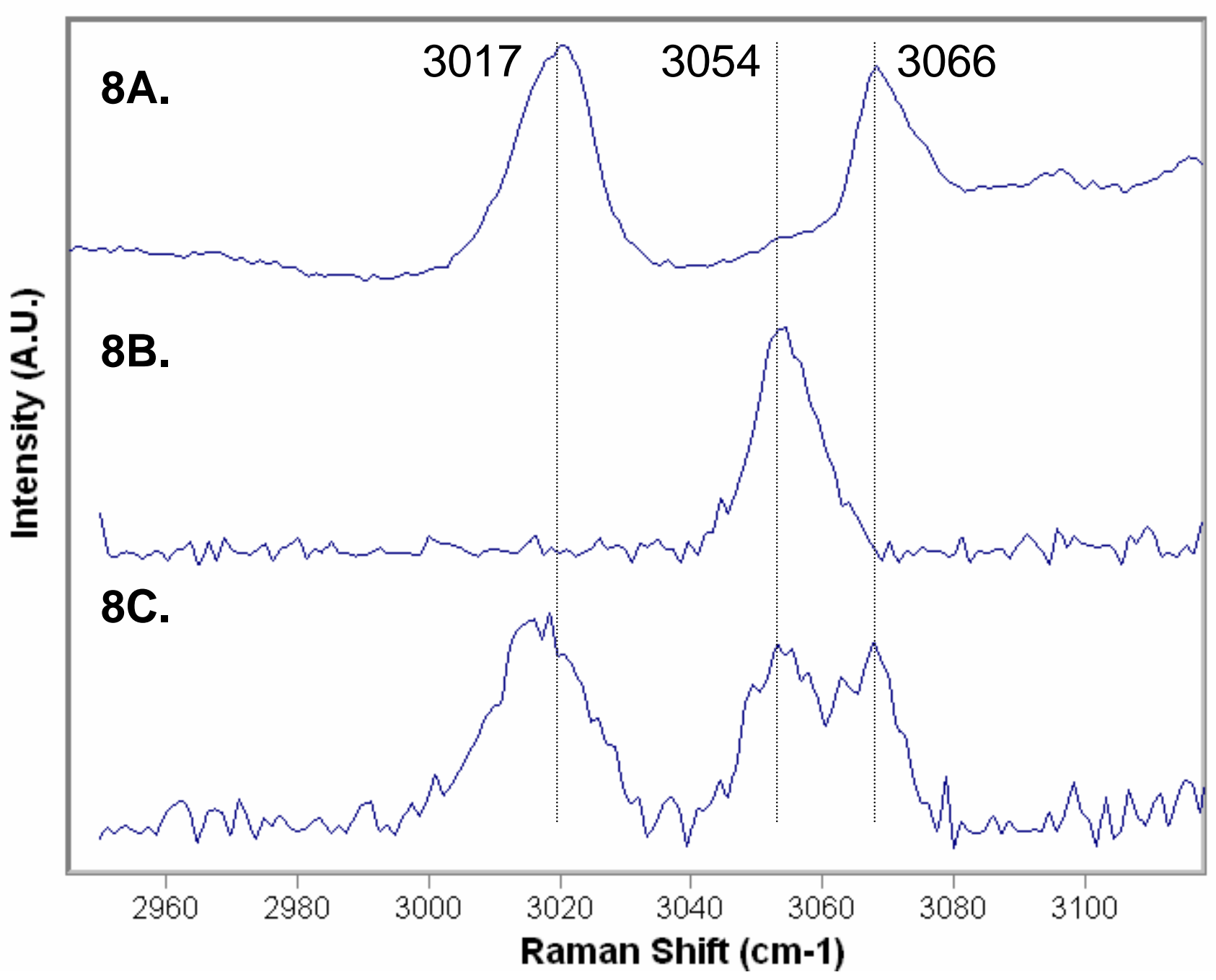

Figure 8. Methane Raman spectra. Spectrum 8A (5 MPa, 278 K, $150 \mathrm{sec}$ (15 sec X 10)) shows two peaks $\left(3017,3066 \mathrm{~cm}^{-1}\right)$ assigned to methane gas. Spectrum 8B (7 MPa, 276 $\mathrm{K}, 200 \mathrm{sec}(20 \mathrm{sec} X 10))$ shows one peak $\left(3054 \mathrm{~cm}^{-1}\right)$ for pure synthetic methane hydrate. Spectra 8C ( $7.7 \mathrm{MPa}, 275.4 \mathrm{~K}, 25 \mathrm{sec}(5 \mathrm{sec} X$ 5)) shows three peaks (3017, 3054 , and $3066 \mathrm{~cm}^{-1}$ ) for a natural hydrate sample measured in situ. Of the three peaks in $8 \mathrm{C}$, two peaks (3017 and $3066 \mathrm{~cm}^{-1}$ ) can be assigned to gas phase methane and 3054 $\mathrm{cm}^{-1}$ can be assigned to methane in the hydrate phase. 


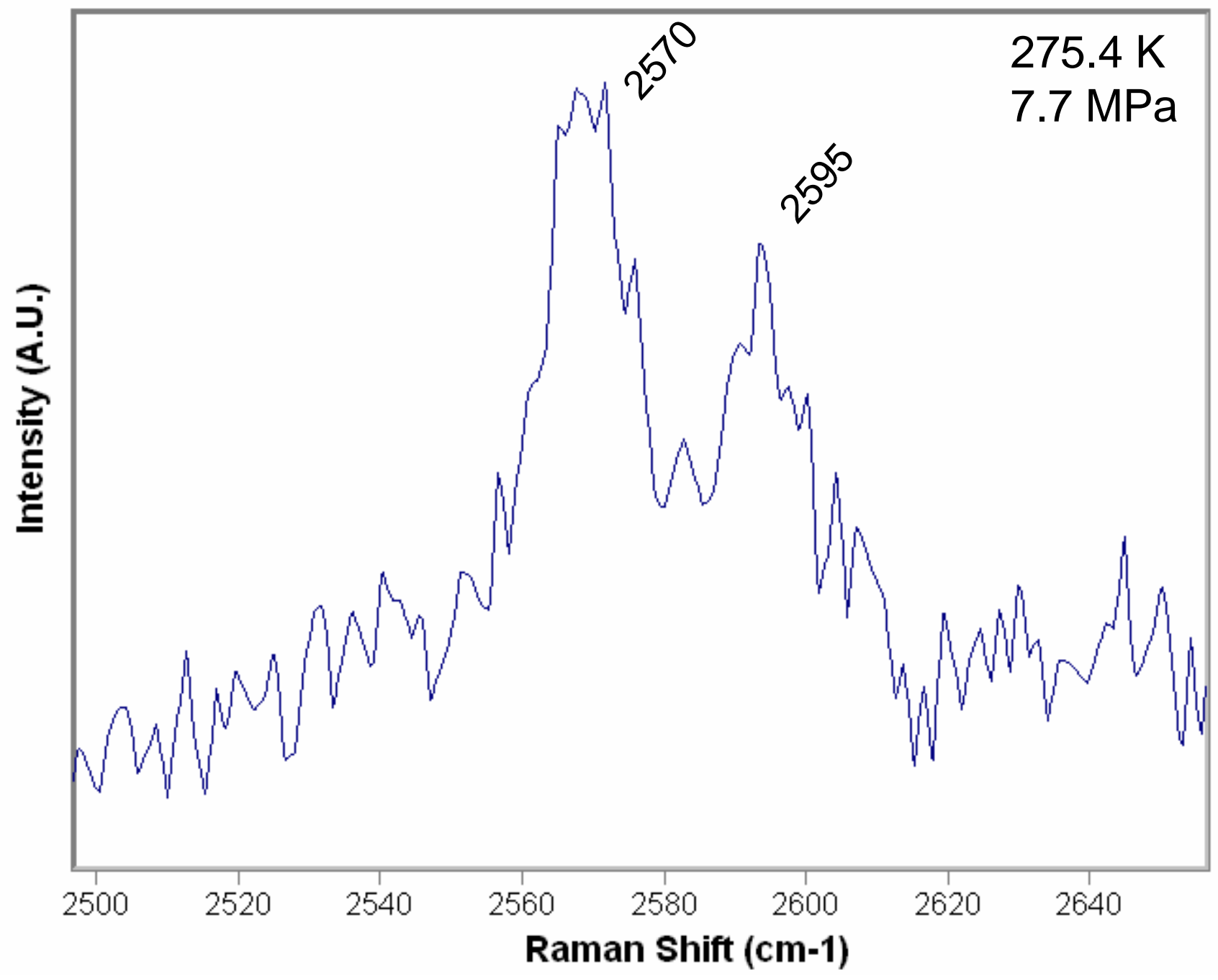

Fig. 9. Raman spectra showing $\mathrm{H}_{2} \mathrm{~S}$ in the $5^{12} 6^{2}$ cage (The peak at $2570 \mathrm{~cm}^{-1}$ is a vibrational mode from methane in the hydrate), (400 sec, $20 \mathrm{sec} \times 20$ ) 


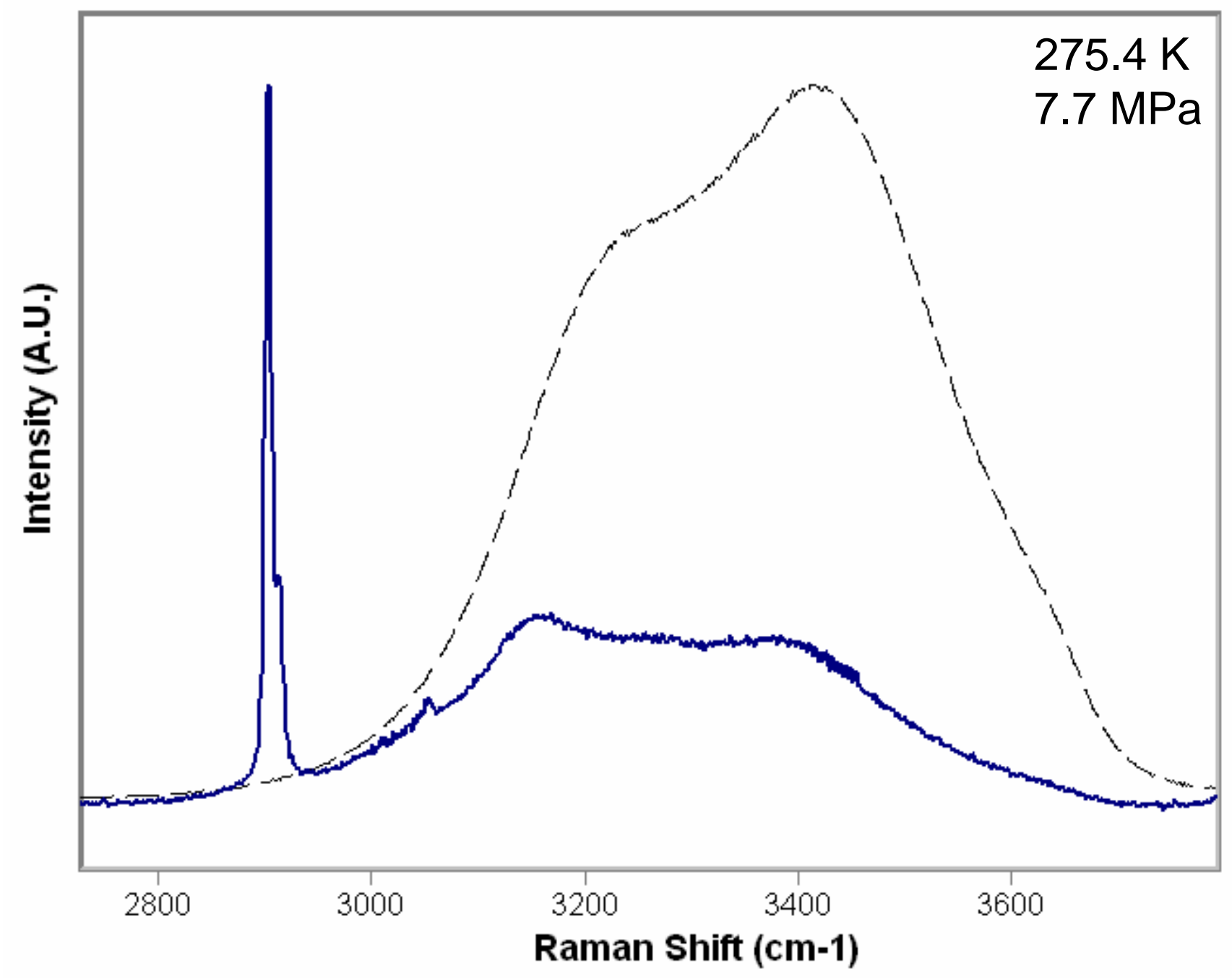

Fig. 10. Raman water $\mathrm{OH}$ stretching region for laboratory methane sl hydrate (solid line, 400 sec $(20 \sec \times 20))$ compared to seawater (dashed line, $150 \mathrm{sec}(15 \mathrm{sec} \times 10))$ 

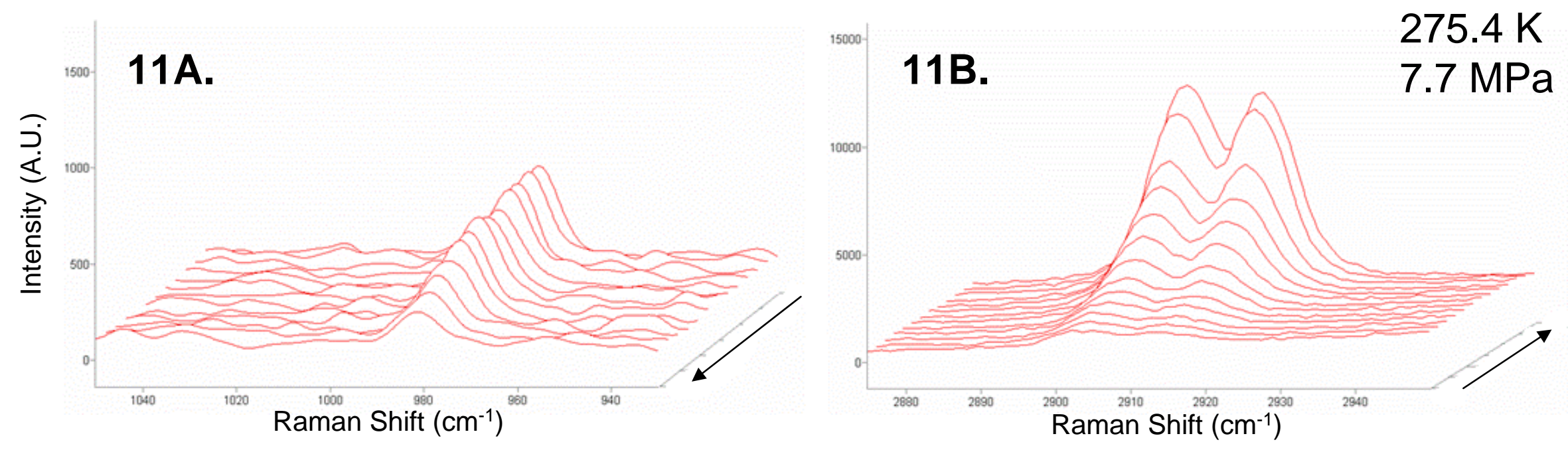

Figure 11. Raman spectra as laser focus moves from seawater to a hydrate sample in situ. Direction of arrow indicates direction of the focal movement into the hydrate sample. Fig. 11A shows the Raman sulfate $v 1$ band decreases as the focus moves from seawater to the hydrate phase. Fig. 11B shows simultaneously the Raman methane $v 1$ bands (indicating hydrate and free gas) increase. All spectra collected for $25 \mathrm{sec}(5 \mathrm{sec} X 5)$. 


\begin{tabular}{clc}
\hline Dive Number & \multicolumn{1}{c}{ Location } & $\Theta_{\mathrm{L}} / \Theta_{\mathrm{S}}$ \\
\hline TD699 & Hydrate Ridge, Site 1 & 1.28 \\
TD699 & Hydrate Ridge, Site 1 & 1.30 \\
TD702 & Hydrate Ridge, Site 1 & 1.03 \\
TD702 & Hydrate Ridge, Site 1 & 1.01 \\
TD699 & Hydrate Ridge, Site 2 & 1.13 \\
\hline
\end{tabular}

Table 1. Methane Occupancy Ratios for hydrates measured in situ at Hydrate Ridge 